\title{
Determinants of Smallholder Crop Commercialization: The Case of Agarfa and Sinana Districts of Bale Zone, Southeastern Ethiopia
}

\author{
Ayalew Sida ${ }^{1}$ Ayele Tessema ${ }^{2} \quad$ Kumneger Shibabaw $^{3}$ \\ 1.Associate Researcher (MSc), Sinana Agricultural Research Center, Oromia Agricultural Research Institute, \\ Ethiopia \\ 2.Assistant Professor (PhD), Faculty of Gender, Environment and Development Studies, Hawassa University, \\ Ethiopia \\ 3.Lecturer (MSc), Faculty of Gender, Environment and Development Studies, Hawassa University, Ethiopia
}

\begin{abstract}
Smallholder crop commercialization entails enhancing market participation and product choice decision of smallholders based on market signal. The study was initiated to identify the current level and determinants of smallholder crop commercialization in Agarfa and Sinana districts of Bale zone. Unlike the previous studies, this study focused on all crops produced by the households. The study used multistage random sampling techniques to select 188 respondents. Primary data was collected using interview schedule, focus group discussion and key informant interview while secondary data was collected from different sources such as records of line offices, Central Statistical Agency and other publications. Both quantitative and qualitative data were collected for the study. Descriptive statistics, household commercialization index (HCI) and truncated regression model were used for data analysis. Accordingly, HCI shows $16 \%$ of households in the sample were fully subsistence oriented while $5.9 \%$ of them categorized as low, $30.9 \%$ medium, $36.7 \%$ high and $10.6 \%$ very high levels of commercialization. Truncated regression depicts that level of education, equine holding (TLU), application of fertilizer, irrigation use, frequency of extension contact, use of credit, membership to cooperatives and social network affected level of commercialization positively and significantly while household size, distance from allweather road and market center affected negatively and significantly. Therefore, to enhance smallholder commercialization, improving and expanding utilization by smallholders to strong institutions such as credit use, adult education, use of irrigation, effective use of production inputs and market oriented extension services should be the key tasks of policy makers and development planners.
\end{abstract}

Keywords: Commercialization, crop, determinants, subsistence production, truncated model

DOI: $10.7176 /$ RHSS/11-9-05

Publication date:May $31^{\text {st }} 2021$

\section{INTRODUCTION}

Agriculture is a mainstay of Ethiopian economy. It contributes about 37 percent of GDP, $37.2 \%$ of export earnings and about 73 percent of the total employment (UNDP, 2018). About $95 \%$ of the total arable land in Ethiopia is cultivated by smallholder farmers which provide more than $90 \%$ of the total agricultural output (Debebe, 2018). However, agricultural production is basically subsistence oriented and dominated by food crops (CSA, 2018). In the literature different researchers assert that such smallholder farming could not secure sustainable livelihood in the long run (Pingali, 1997; Berhanu and Moti, 2010; Abafita et al., 2016). Instead, commercialization of smallholder farming is supposed to be an important pathway to reduce poverty and enhance development of the nation. It would increase income and purchasing power, as well as reduces smallholders' vulnerability to food insecurity (Afework and Endrias, 2016).

Cognizant of this, the government of Ethiopia has promoted smallholder commercialization as a key policy issue since 2005 in order to bring a dynamic change. It opts to transform subsistence agriculture to commercialized agriculture by introducing improved agricultural technologies and farm implements which supports intensification of marketable farm products, and specialization towards more tradable crops (Sharp et al., 2007; Gutu, 2017). Based on this, Agricultural Commercialization Clusters (ACCs) were formed and implemented in different parts of the country with the prime role of Agricultural Transformation Agency (ATA) in which specialization, diversification and commercialization of smallholder farming were given much attention (Pauw, 2017). However, despite the efforts made to commercialize and transform subsistence oriented crop production in Ethiopia, there is not much change in farmers' lives and practices (NPC, 2016). Studies indicate that the main factors for this include population growth, low access to appropriate technologies, lack of strong institutions, high risks, low market integration, high transaction costs, and low asset holdings (Berhanu and Moti, 2010; Abafita et al., 2016; Afework and Endrias, 2016; Alelign et al., 2017; Addisu, 2018; Getahun, 2018).

Except a few empirical works (e.g. Berhanu and Moti, 2010), most of the previous studies (e.g. Alelign et al., 2017; Addisu, 2018; Getachew, 2018) used market participation of a specific crop (focusing on a single crop 
in most cases) as a proxy to analyze the determinants of smallholder commercialization. But, using market participation of a single crop as a proxy may not reveal the real status of commercialization due to the fact that households often produce diverse crops at the same time. As a result, the task of measuring level of smallholder crop commercialization should consider all crop activities undertaken by the farm household. Even though a few empirical works were conducted in the country to address the aforementioned gaps, there is lack of information in the study area concerning determinants of smallholder crop commercialization. Therefore, this study was initiated with two specific objectives; i) to assess level of crop commercialization; ii) to identify factors affecting crop commercialization level of smallholders in the study area.

\section{Methodology}

\subsection{Description of the Study Area}

The study was carried out in Agarfa and Sinana districts of Bale zone. The districts are found at a distance of 465 $\mathrm{km}$ and $430 \mathrm{~km}$ to southeast of Addis Ababa, respectively. About $90 \%$ of Sinana district is characterized by highland agro-ecology while the remaining 10\% belongs to the midland agro-ecology. The district has 20 rural kebeles and 4 rural towns. According to the Central Statistical Authority (Population Census, 2007), the population of Sinana district was 119,208 of which 62,280 were male and 56,928 female. $95 \%$ of the population reside in rural areas while the rest in surrounding small towns. The land use of the district is characterized with $63 \%$ crop land, $11.78 \%$ grazing land, $7.5 \%$ forested and about $0.07 \%$ barren/degraded land. The major crops grown in the district include wheat, barley, Faba bean, field pea, lentil, potato, onion, pepper and emmer wheat (SDANRO, 2017).

Agarfa district, on its part, has 20 kebeles and 2 towns with a total land area of $1343 \mathrm{~km}^{2}$ out of which $45 \%$ is arable land, 30\% grazing land, 12\% forested, and 5\% barren/degraded land. According to the Central Statistics Authority (Population Census, 2007), the population of the district was 104,412 out of which 53,276 were male and 51,136 female. It is estimated that 90,852 (86.8\%) were rural dwellers while the remaining represented urban dwellers. More than $95 \%$ of the population is engaged in agriculture. The agro-ecological zones of the district are highland (83\%), midland $(11 \%)$ and lowland $(6 \%)$. Altitude in the district ranges from $1250 \mathrm{~m}$ to $3855 \mathrm{~m}$ a.s.l. The major crops grown in the district includes wheat, barley, faba bean, field pea, maize, pepper, potato and onion (ADANRO, 2017).

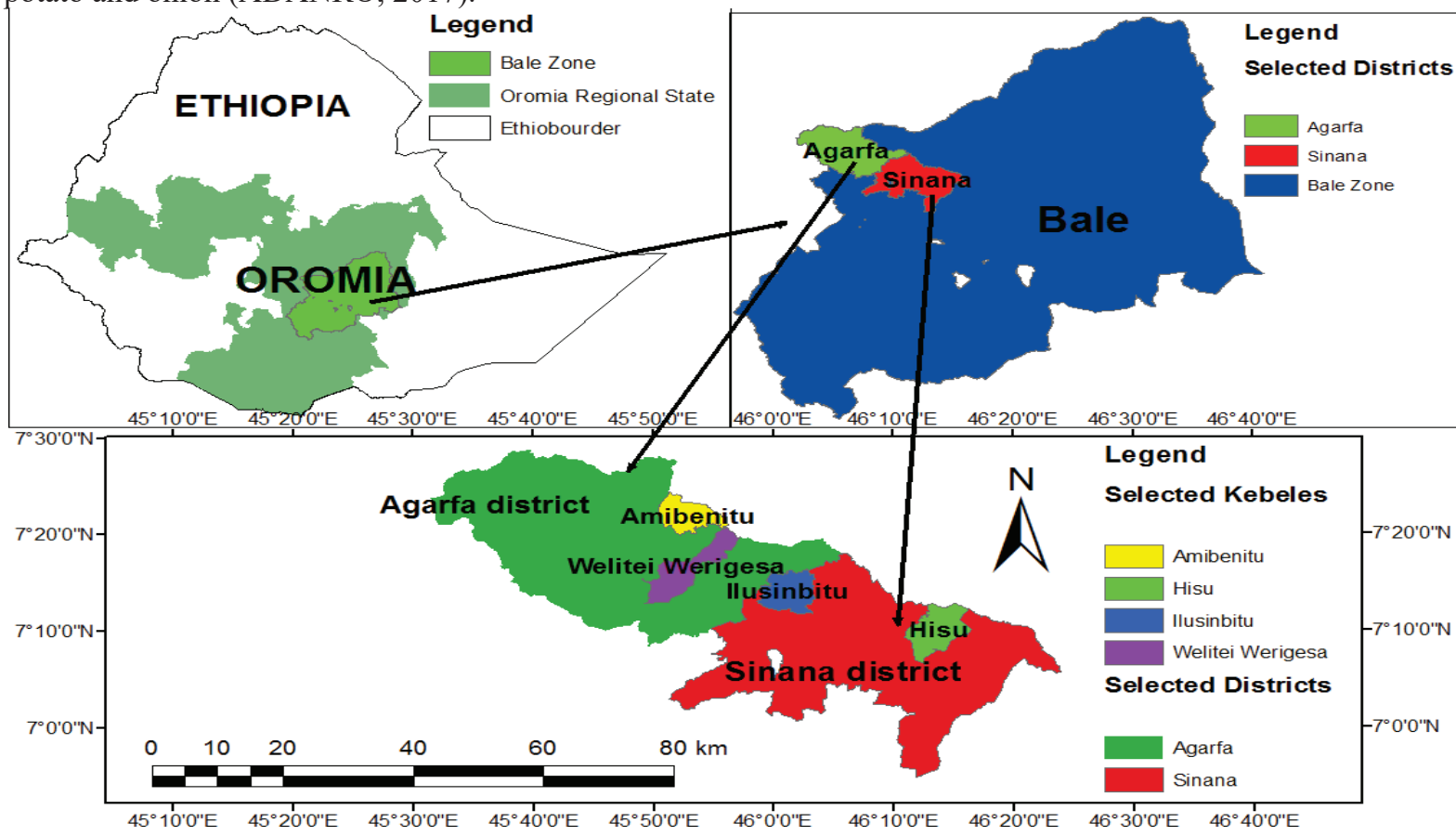

Figure 1: Map of the study area

\subsection{Research Design}

Cross-sectional research design that involved the collection of quantitative and qualitative data components was used for the purpose of this study. As cross-sectional design enables the collection of the desired data at a single point in time in a relatively less expensive way, it was regarded as appropriate for this study.

\subsubsection{Sampling techniques and procedures}

Multistage random sampling technique was employed to select the study areas and the ultimate sample respondents. In the first stage, two districts namely Sinana and Agarfa districts were selected randomly among 
the highland districts of Bale zone with similar farming system. In the second stage, two representative kebeles were drawn from each district by employing simple random sampling technique in order to allow equal chance for all kebeles to be considered in the sampling procedure. Accordingly, Ambentu and Weltei Wergessa (Elani) kebeles were selected from Agarfa district while Hisu and Ilusanbitu kebeles were selected from Sinana district. In the third stage, the required sample size of respondents from each kebele was determined based on probability proportional to size (PPS) sampling method. Finally, the ultimate sample respondents were picked up by using systematic random sampling procedure using the sampling frame found in each respective Kebele Administration Offices.

\subsubsection{Sample size determination}

Constraints such as resource, logistic, human resource, budget and time limitations determine the sample size of the study. There are some sample size determination techniques which were developed by different scholars. Among these techniques, the sample size determination technique developed by Kothari (2004) is mainly used by different researchers. For instance, Falmata (2018) used Kothari's formula to determine the sample size. The current study also employed a simplified formula provided by Kothari to determine the required sample size at $95 \%$ confidence level and the desired level of precision at $5 \%(0.05)$;

$$
\mathrm{n}=\frac{\mathrm{Z}^{2} \mathrm{pqN}}{\mathrm{e}^{2}(\mathrm{~N}-1)+\mathrm{Z}^{2} \mathrm{pq}}=188
$$

Where, $\mathrm{n}$ is the desired sample size; $\mathrm{Z}$ is the level of confidence with the value of 1.96; e is the desired level of precision; $p$ is the estimated proportion of an attribute (degree of variability) present in the population with the value of 0.15 as suggested by Falmata (2018) to get the desired minimum sample size of households at $95 \%$ confidence level and $\pm 5 \%$ precision; $q=1-p$; and $N$ (4696) is the total number of rural households in the four kebeles of the two districts. Based on the aforementioned formula a total of 188 of sample households were considered during the interview schedule.

Table 1: Distribution of sample households in sample Kebeles

\begin{tabular}{lllll}
\hline Districts & Sample Kebeles & $\begin{array}{l}\text { Total Number of } \\
\text { Households }\end{array}$ & $\begin{array}{l}\text { Number of Sample } \\
\text { Households }\end{array}$ & $\begin{array}{l}\text { Proportion of Sampled } \\
\text { households }\end{array}$ \\
\hline Agarfa & Ambentu & 1130 & 45 & 0.24 \\
& Elani & 1150 & 46 & 0.244 \\
Sinana & Hisu & 1162 & 47 & 0.25 \\
& IluSanbitu & 1254 & 50 & 0.266 \\
\hline Total & 4 & 4696 & 188 & 1.00 \\
\hline
\end{tabular}

Source: Author's own computation from data of Agarfa and Sinana districts, Office of Agricultural and Natural Resource, 2020

\subsection{Sources and Types of Data}

Primary and secondary data, both of quantitative and qualitative nature, were used to achieve the objectives of the study. Primary data was collected from sample respondents, focus group discussants and key informants while secondary data was collected from different sources such as records of line offices, the Central statistical Authority and other publications. Qualitative data types include production and marketing constraints in the study areas. The quantitative data types mainly included the amount of input used in production of each crops; the total output (yield) obtained from each crop, and the amount of produce supplied to the market by each household for each crop.

\subsection{Methods of Data Collection}

The data collection methods employed for the purpose of this study included interview schedule, focus group discussions (FGD) and key informant interviews. Semi-structured questionnaire was used as a data collection tool for face to face personal interviews (interview schedule) to collect primary data from sample households while checklists were prepared to collect data from focus group discussants and key informant interviewees. Before conducting the formal survey, questionnaire pre-testing was carried out on eight farmers to evaluate the sequence, clarity and interpretation of the questions, relevance of the questions, to estimate the time required for an interview and to shape the questionnaire according to the feedback from pre-testing. Moreover, a total of four FGDs (one FGD in each sampled kebele) were carried out to collect the desired primary qualitative data. The size of FGD participants ranged from six to nine. The participants of the FGD were farmers that were not included in the individual interview and gender inclusive in which both adults and the youth were included with respective male and female composition. Likewise, the elder farmers, agricultural experts and traders were targeted for the key informant interview. 


\subsection{Method of Data Analysis}

Descriptive statistics, household commercialization index (HCI) and econometric models were employed for data analysis.

Crop output market participation index (COMPI): To answer the first objective, HCI was measured as the ratio of total quantity of all annual crops sold to the total quantity of all annual crops produced by households, multiplied by 100. Past studies conducted by Gutu (2017), and Berhanu and Moti (2010) used this index to measure level of agricultural commercialization by smallholders from the output side. COMPI formula, which was adopted from these researchers, is expressed mathematically as:

$$
\text { COMPI }_{i}=\frac{\text { The sum of Gross value of Crops Sold by House hold " } \mathrm{i} \text { " in a Year " } \mathrm{j} "}{\text { The sum of Gross Value of Crops Produced by Household "i" in a Year " } \mathrm{j} "} * 100
$$

Where, $\mathrm{COMPI}_{\mathrm{i}}=$ Commercialization index of $\mathrm{i}^{\text {th }}$ household in annual crops sales expressed as a percentage. COMPI has a value between zero and one hundred, inclusive. A value closer to zero indicates a subsistenceoriented household and a value closer to one hundred implies highly commercialized household (Osmaniet al., 2014).

Moreover, truncated model was employed for econometric analysis. The dependent variable in this study is level of commercialization. The formal model of level of crop commercialization equation is given below.

$\mathrm{Yi}^{*}=\beta^{\prime} \mathrm{xi}+\mu \mathrm{i}$,

$\mathrm{Yi}=\mathrm{Yi}^{*}$, if $\mathrm{Yi}^{*}>0$ and $\mathrm{Di}^{*}>0$

$\mathrm{Yi}=0$, otherwise,

Where, $\mathrm{Yi}^{*}$ and $\mathrm{Yi}$ are latent and observed levels of commercialization, respectively.

Table 2: The hypothesized effects of independent variables on level of commercialization

\begin{tabular}{lllc}
\hline Variables & Type & Measurement of variables & $\begin{array}{c}\text { Expected } \\
\text { Effect }\end{array}$ \\
\hline Sex of household head & Dummy & Female-1, otherwise 0 & - \\
Household size & Continuous & Number & - \\
Education level of HH & Continuous & Number of years & + \\
Farm size & Continuous & Hectare & + \\
Livestock ownership & Continuous & TLU & $+/-$ \\
Equines ownership & Continuous & TLU & + \\
Non/off-farm income & Continuous & ETB & $+/$ \\
Credit use & Dummy & If HH uses credit=1, otherwise, 0 & - \\
Distance from all-weather road & Continuous & Minutes of walk & + \\
Frequency of extension contact & Continuous & Number of days & + \\
Access to market information & Dummy & If HH has access=1,otherwise 0 & - \\
Distance from market center & Continuous & Minute of walk & + \\
Cooperative membership & Dummy & If HH is member=1, otherwise 0 & + \\
Social network & Dummy & If HH has s/network=1, otherwise & + \\
& & 0 & + \\
Use of Improved seed & Dummy & If yes=1, otherwise 0 & + \\
Application of fertilizer & Dummy & If yes=1, otherwise 0 & + \\
Use of irrigation facilities & Dummy & If HH use irrigation=1, otherwise 0 & + \\
\hline
\end{tabular}

Source: Own formulation from theoretical and empirical literatures and authors view

\section{RESULTS AND DISCUSSION}

\subsection{Summary of Descriptive Statistics}

As it was shown in the Table 3 below, the average formal schooling of the total sampled household heads was 4.212 with the standard deviation of 3.877. Similarly, the average household size for the total households in the sample was found to be 6.712 with the standard deviation of 3.108. The average size of land allotted for crop production in the 2018/2019 production year was 2.789 hectares with the respective standard deviation of 1.686 . Moreover, the average livestock ownership was 5.870 TLU with standard deviation of 3.529. The average equine ownership by the total households in the sample was found to be 1.396 TLU with the respective standard deviation of 1.344. The average income obtained from non/off-farm activities was 6729.787 Ethiopian birr with standard deviation of 14451.760. Furthermore, the average time households expected to travel to get all-weather road was 22.330 minutes with standard deviation of 15.012. Similarly they also travelled in average about 27.537 minutes to reach the nearest market center with the standard deviation of 15.928. The average frequency of extension contact of the total households in the sample was about seven days (6.973) with standard deviation of 7.640 
Table 3. Summary of descriptive statistics for continuous variables

\begin{tabular}{lcc}
\hline Continuous Variables & Mean & Standard Deviation \\
\hline Education level of household head (Years of schooling) & 4.212 & 3.877 \\
Household size (Number) & 6.712 & 3.108 \\
Farm size allocated for crop production (Hectare) & 2.789 & 1.686 \\
Total livestock Ownership (Tropical Livestock Unit) & 5.870 & 3.529 \\
Equine ownership (Tropical Livestock Unit) & 1.396 & 1.344 \\
Non/off-farm income (Ethiopian birr) & 6729.787 & 14451.760 \\
Distance from all-weather road (minutes of walk) & 22.330 & 15.012 \\
Distance from nearest market center (minutes of walk) & 27.537 & 15.928 \\
Frequency of extension contact (number of days) & 6.973 & 7.640
\end{tabular}

Source: Author's own computation from survey data, 2020

Moreover, as it was indicated in the Table 4, the majority of the households in the sample were maleheaded (86\%) while female-headed households represented only 14\%. Regarding the use of improved seeds, $68 \%$ of the sampled households used improved varieties of different crops while the rest $32 \%$ did not use for any crop. Out of the total sampled households, $93.1 \%$ of the sample households applied inorganic fertilizer during crop production while the remaining $6.9 \%$ of the total households did not apply any inorganic fertilizer On the other hand, only $19.7 \%$ of the households had used irrigation facilities while the majority $(80.3 \%)$ did not benefit from irrigation facilities due to lack of irrigation schemes in their locality. In the study area, the majority of households in the sample have access to market information. Accordingly, $81.4 \%$ of the sampled households had access to market price information while the remaining $18.6 \%$ did not. Access to credit could enhance smallholder commercialization by solving cash constraints that could face farmers during planting through enabling the users on time to purchase production inputs. However, only about $31 \%$ of the households in the sample used credit in the 2018/2019 fiscal year. Concerning the status of cooperative membership, $69.68 \%$ of the total households in the sample were organized under cooperatives. Moreover, about $89.36 \%$ of the total households in the sample had social networks (participated in different locally available formal and informal social organizations).

Table 4: Summary of descriptive statistics for dummy variables

\begin{tabular}{lll}
\hline Dummy variables & & Percentages \\
\hline Sex of household head & Male & 86 \\
& Female & 14 \\
\hline Use of improved Seed & No & 32 \\
& Yes & 68 \\
\hline Use of inorganic fertilizer & No & 6.915 \\
& Yes & 93.085 \\
\hline Use of irrigation & No & 80.319 \\
& Yes & 19.681 \\
\hline Access to market information & No & 18.617 \\
& Yes & 81.383 \\
\hline Use of credit & No & 69.149 \\
& Yes & 30.851 \\
\hline Membership to cooperatives & No & 30.319 \\
& Yes & 69.681 \\
\hline Social Network & No & 10.638 \\
& Yes & 89.362 \\
\hline
\end{tabular}

Source: Author's own computation from survey data, 2020

\subsection{Commercialization Level of Smallholders in the Study Area}

This section addresses the first objective of the study. Commercialization level of households was addressed by using household commercialization Index (HCI) calculated from the share/proportion of the value of output sold from the value of total production for each crop. This tells to what extent households supplied to market the output harvested during the 2018/2019 production year. The result of household commercialization index (HCI) showed that on average households in the sample supplied $44.64 \%$ of their total production to the market which ranged from a minimum of 0 to the maximum of $91 \%$, where 0 supply indicates the household operates fully at subsistence level while $91 \%$ implies the highest level of commercialization.

The calculated commercialization indices help to categorize households into different groups based on their 
commercialization levels. Based on the classification undertaken by Gutu (2017), households could be grouped into full subsistence, low commercialization, medium commercialization, high commercialization and very high level of commercialization if their marketed produce is 0 , less than $25 \%, 25 \%-50 \%, 50 \%-75 \%$ and more than $75 \%$, respectively. Accordingly, the commercialization level of households in the study area was categorized in one of the above-mentioned groups as shown in Figure 2. Based on this, 16\% of the households in the sample did not participate in the output market at all. On the other hand, 36.7\% of households provided 50-75\% of their products to the market while $5.9 \%$ of the households supplied greater than 0 but less than $25 \%$ of their produce.

\section{Crop commercialization level of households in the study area}

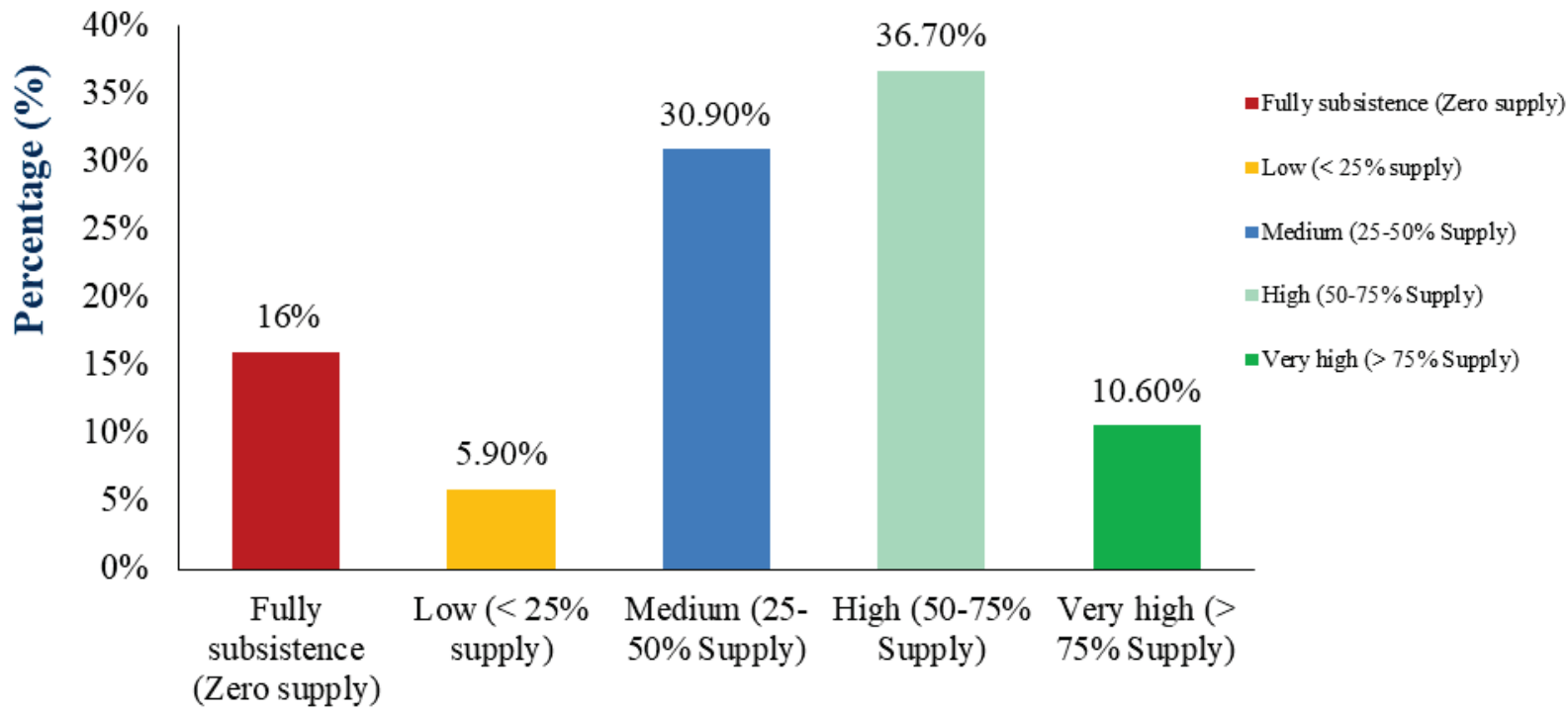

Levels of Commercialization

Moreover, crop specific output market participation index was calculated using the proportion of output sold from the value of the total crop production which is considered as an important indicator of the commercial behavior of sample households. Calculating crop specific market participation index would help to identify the more market oriented crop enterprise and give much emphasis on such crop during resource allocation. The descriptive result of crop specific commercialization index is illustrated in Table 5. Among all crops produced by the sampled households, potato market participation index takes the highest mean value of 0.87 with standard deviation of 0.167 . This indicates that potato is a more market oriented crop in the area and less of its produce used for home consumption. On the contrary, the lowest mean (0.36) of market participation index was recorded for maize crop which shows that maize is the least market oriented crop enterprise in the study area. Most of the farmers in the study area produce maize mainly for the purpose of consumption and animal feed. Table 5: Crop output market participation indices of sampled households

\begin{tabular}{lcc}
\hline Market participation indices (in percentage) & Mean & Standard deviation \\
\hline Market participation index of aggregated crops & 46.32 & 28.44 \\
Wheat market participation index & 46.49 & 26.38 \\
Barley market participation index & 20.04 & 22.11 \\
Faba bean market participation index & 27.09 & 27.83 \\
Field pea market participation index & 18.89 & 23.98 \\
Potato market participation index & 87.08 & 16.68 \\
Teff market participation index & 20.37 & 30.93 \\
Pepper market participation index & 69.11 & 36.34 \\
Emmer wheat market participation index & 46.16 & 36.29 \\
Lentil market participation index & 59.17 & 44.17 \\
Linseed market participation index & 84.76 & 19.42 \\
Maize market participation index & 3.57 & 11.44 \\
Onion market participation index & 73.52 & 34.52 \\
\hline
\end{tabular}

Source: Author's own computation from survey data, 2020 


\subsection{Factors affecting level of crop commercialization}

This section analyzes the major contributing factors which possibly affect the level of crop commercialization among farm households. The truncated regression model through left truncation limited to zero and right truncation limited to hundred was employed to achieve the research objective. The model was statistically significant at less than $1 \%$ level of significance, indicating the goodness of fit of the model to explain the relationships of the hypothesized variables in terms of at least one explanatory variable. The result of the model analysis displays that out of the seventeen explanatory variables considered in the analysis, eleven of them significantly affected household level of commercialization in the crop output market. Accordingly, commercialization level of households in the study area was significantly influenced by level of education, household size, number of equine holding, application of chemical fertilizer, use of irrigation, distance from allweather road, distance from nearest market center, frequency of extension contact, use of credit, membership to cooperatives and participation in social organizations (Table 6). These variables are discussed one by one as the follows.

Educational level of the household head: The result of the truncated regression illustrates the existence of positive and significant association between educational level of the household and level of commercialization. The model result depicts, keeping other factors constant, as level of education of the household head increases by one year of formal schooling, the level of crop commercialization increases by $0.37 \%$ at less than $1 \%$ significance level. The result supports the finding reported by Addisu (2018) who found that a year increase in educational level of the household head would results in $0.50 \%$ increase on level of teff commercialization at less than $10 \%$ level of significance. It is also consistent with the report of Taye et al. (2018) who explained that, on average, an onion producer who get educated, would increase the amount of onion market by 0.14 quintal at less than $5 \%$ of significance level. The finding of the current study affirms the fact that educated households are more likely to access and equipped with better negotiation skill, better access to information and have ability to process information, and make better use of their available resources (Berhanu and Moti, 2010; Tadeleet al., 2017).

Household size: As was hypothesized, the number of household members affected the level of household commercialization negatively at less than $1 \%$ level of significance. It is found that as the number of household size increases the level of household commercialization in the crop output market decreases. Consequently, the result of the model signifies, keeping other factors constant, an increase in the number of household by one person would lead to $0.72 \%$ decrease on the level of household commercialization in the crop output market. This finding is comparable with the result obtained by Tadele et al. (2017) which states that as family size increases by one person, the level of wheat commercialization decreases by $0.0024 \%$ at less than $1 \%$ significance level. This could be because as the number of people living under the umbrella of one household gets larger, the amount of produces consumed in the home increases resulting in decrease in the share of crop outputs supplied to the market.

Number of equine holding (TLU): As it was expected, the more the household possess equine, the higher the level of commercialization the household has in crop output market. Equine holding (TLU) was found to correlate with level of commercialization positively and significantly. The result of truncated regression analysis indicates that as the number of equine owned by the household rise by one TLU, the expected level of commercialization increases by $2.88 \%$ ceteris paribus at less than $1 \%$ level of significance. The result is similar with what has been reported by Andualem (2017) who found that as the number of equine owned by the household increases by one unit, the amount of wheat supplied to the market increases by $0.05 \%$. The result is also in line with the findings by Addisu (2018) which showed that an increase on the number of equine by one TLU would increase the level of teff commercialization by $1.33 \%$.

Application of chemical fertilizer: As was hypothesized, the result of the study indicates fertilizer application has positive and significant impact on the level of crop commercialization. It depicts that, keeping other factors constant, the household who applied chemical fertilizer during crop production is more likely to increase level of crop commercialization by $11.38 \%$ at less than $1 \%$ level of significance. The result is in line with the finding by Getachew (2018) who reported that the household who applied chemical fertilizer in teff production tend to increase level of teff commercialization by $24 \%$ in the output market at less than $1 \%$ significance level. Alelign et al. (2017) also found that application of chemical fertilizer in crop production would increase the level of crop commercialization by $2.41 \%$ at less than $5 \%$ level of significance. This could be due to the fact that application of chemical fertilizer in crop production could results in surplus available for market purpose.

Use of irrigation: As it was hypothesized, there is positive and significant association between level of commercialization and the use of irrigation. Accordingly, the result of truncated regression analysis depicts, keeping other factors constant, the household who used irrigation is more likely to increase level of commercialization in the crop output market by $3.08 \%$ than others at less than $5 \%$ significance level. The result is consistent with the result obtained by Alelign et al. (2017) who reported that for every one hectare increase on the size of irrigable land used by the household, there would be $40.85 \%$ increase on the level of crop 
commercialization in the output market at less than $1 \%$ level of significance. The finding of this study supports the general truth in which the use of irrigation is among the factors attributed for enhancement of household commercialization by increasing surplus production.

Distance from all-weather road: The result of the model shows the existence of negative and significant relationship between level of household commercialization and the minutes of walk travelled to reach allweather road. Keeping other factors constant, one minute increase to the distance from residential area to allweather road leads to $0.22 \%$ decrease on the level of household crop commercialization at less than $1 \%$ level of significance. The result is in line with the finding of Berhanu and Moti (2010) who reported that a one kilometer increase of distance from a settlement center to the nearest all weather road would result in $0.22 \%$ decrease on the level of crop output market participation. Based on the result and empirical finding, the household who resides far away from all-weather road, do not have the chance of easily accessing transportation options. As a result, the level of commercialization of the households decreases in the crop output market.

Table 6: Factors affecting level of smallholder crop commercialization (Truncated regression).

\begin{tabular}{|c|c|c|c|}
\hline Variables & Coefficient & Robust Std. Err. & Z \\
\hline Sex of household head & -.565 & 2.049 & -0.28 \\
\hline Educational level of household head & $.375 * *$ & .185 & 2.03 \\
\hline Household size & $-.717 * * *$ & .267 & -2.68 \\
\hline Farm size & .864 & .548 & 1.57 \\
\hline Number of livestock (TLU) & .065 & .211 & 0.31 \\
\hline Number of equine (TLU) & $2.876 * * *$ & .544 & 5.29 \\
\hline Non/off-farm income & $2.20 \mathrm{e}-06$ & .0000519 & 0.04 \\
\hline Use of improved seed & 1.212 & 2.161 & 0.56 \\
\hline Application of chemical fertilizer & $11.382 * * *$ & 3.198 & 3.56 \\
\hline Use of irrigation facilities & $3.078 * *$ & 1.573 & 1.96 \\
\hline Distance from all-weather road & $-.222 * * *$ & .080 & -2.79 \\
\hline Distance from nearest market center & $-.228 * *$ & .106 & -2.15 \\
\hline Access to market information & 5.717 & 3.418 & 1.67 \\
\hline Frequency of extension contact & $.340 * * *$ & .129 & 2.63 \\
\hline Use of credit & $7.296 * * *$ & 1.840 & 3.96 \\
\hline Membership to cooperatives & $5.639 * *$ & 2.518 & 2.24 \\
\hline Social network & $6.188 * *$ & 2.924 & 2.12 \\
\hline /sigma & $8.315 * * *$ & .597 & 13.93 \\
\hline $\begin{array}{l}\text { Number of observation }=158 \\
\text { Prob }>\mathrm{chi}^{2}=0.0000\end{array}$ & $515.33 \log$ & -555.52808 & \\
\hline
\end{tabular}

Symbols $* *$ and $* * * *$, indicate statistical significance level at $5 \%$ and $1 \%$, respectively.

Source: Author's own computation from survey data, 2020

Distance from the nearest market center: Similar to the distance travelled to get all-weather road, the minutes of walk travelled to reach the nearest market center also negatively and significantly correlate with level of household commercialization in the crop output market. The result of the model depicts that as the distance to reach the nearest market center increases by one minute, the level of household commercialization in the crop output market decreases by $0.23 \%$ ceteris paribus at less than $5 \%$ level of significance. The result is consistent with the finding reported by Gutu (2017) who found that a one hour increase of the distance from the market causes a considerable decrease in the degree of crop commercialization by 0.069 at less than $1 \%$ level of significance. This implies that as distance from market center to the residential place increases, the expected transport cost incurred by the household in crop marketing rises thereby discouraging market participation. In addition, it is believed that the household who lives far away from the market center is less likely to access the market information than the household who live nearby to the market place. Therefore, the level of household commercialization decreases in the crop output market for the households who live far away from market center. Frequency of extension contact: As was hypothesized, the frequency of extension contact is found to influence household level of commercialization in the crop output market positively and significantly. The finding illustrates, keeping other factors constant, as the frequency of extension contact increases by one day, the expected level of household commercialization in the crop output market increases by $0.34 \%$ at less than $1 \%$ significance level. The result is similar to what has been reported by Getachew (2018) which shows a one day increase in the frequency of extension contact leads to $0.72 \%$ increase in the proportion of the amount of teff supplied to the market at less than 1\% level of significance. The study by Edosa (2018) also portrays a comparable result in which an additional unit increase in extension contact measured in terms of a number of days, would result in $0.37 \%$ increase to the level of teff commercialization at less than $10 \%$ significance level. The result implies that households who get extension contact frequently would be more likely to access and use new productive technologies and production packages, and market information. Therefore, he/she would tend to 
increase the level of commercialization in crop output market.

Use of credit: Access to credit plays an important role in solving cash constraints that is needed to purchase inputs such as fertilizers, improved seeds and herbicides that are used to enhance crop production and productivity which in turn has a positive effect on marketable surplus (Tadele et al., 2017). The result of this study clearly indicates the existence of positive and significant association between access to credit and level of commercialization in the crop output market. The result of truncated regression reveals, keeping other factors constant, household who had access to credit is more likely to increase the level of commercialization in the crop output market by $7.30 \%$ than others at less than $1 \%$ significance level. The result is comparable with the finding of Andualem (2017) who stated that one time increase in credit utilization would result in a 3.712 quintals increase in the amount of wheat sold at less than $5 \%$ level of significance. This could be because access to credit offers an opportunity to solve cash constraints that may face the household during crop production and marketing.

Membership to cooperatives: Consistent with prior expectation, being a member of a certain cooperatives is found to influence the level of household commercialization positively and significantly. Accordingly, the result of truncated regression, keeping other factors constant, households who were grouped under a certain cooperatives were $5.64 \%$ more likely to increase level of commercialization in the crop output market than others at less than 5\% level of significance. The result is comparable with the finding reported by Assefa et al. (2019), who found that for households who were members of farmers' cooperatives, the likelihood to commercialize pulse crop production increased by $7.1 \%$ ceteris paribus. The result suggests that a household who is a member of agricultural cooperatives tend to get an opportunity to access production inputs at a reasonable price which may result in surplus production.

Social network: As was hypothesized, participation in formal and informal social organizations such as eder, debo, mehaber, women association, water use association and youth association have positively and significantly affected the household's level of commercialization in crop output market. The result of truncated regression indicates, keeping other factors constant, household who had participated in such social organizations was $6.19 \%$ more likely to increase its level of crop commercialization than others at less than $1 \%$ level of significance. The result is comparable with the result reported by Asfaw et al. (2018) who found that farmers who participated in different social organizations had increased their level of potato commercialization by $5.67 \%$ than others at less than $1 \%$ level of significance. This is could be due to the fact that households who participated in different social organizations are more likely to participate in collective actions in which different information, experience and knowledge are shared. This in turn help to improve the skill of information utilization related to new technologies and market information which eventually leads to an increase on the household's level of commercialization in the crop output market.

\section{CONCLUSION AND RECOMMENDATIONS}

\subsection{Conclusion}

This study identified factors affecting commercialization level of smallholder crop production as well as the current level of commercialization in Agarfa and Sinana districts of Bale zone. The result of household commercialization index (HCI) indicated the average crop commercialization level of households in the sample was $44.64 \%$, ranging from a minimum of 0 (zero) to a maximum of $91.04 \%$. This indicates the existing wide gap among households with respect to the level of crop commercialization arising from different factors that affected the level of household commercialization in different ways.

The result of truncated regression model depicts that level of education, number of equine (TLU), application of chemical fertilizer, use of irrigation, frequency of extension contact, use of credit, membership to agricultural cooperatives and social network were found to positively and significantly increase the level of household crop commercialization. On the contrary, household size, distance from all-weather road and distance from nearest market center affected commercialization level of smallholders negatively and significantly. This could be due to the reason that as the distance from such facilities increases, the households would be less likely to easily transport their output to market as well as forced to pay high cost for transportation. Therefore, they tend to decrease the amount of outputs targeted for market supply.

\subsection{Recommendations}

The following are some relevant recommendations that are drawn from the findings of the current study. It is believed that they can serve as important input in designing appropriate interventions to improve smallholder crop commercialization in the study area.

i. The frequency of extension contact undertaken by agricultural experts was found to positively and significantly enhance the level of smallholder crop commercialization. Therefore, agricultural experts and other development practitioners should have to provide market oriented extension services in addition to production based extension services in the study area. 
ii. The application of chemical fertilizer affected smallholder crop commercialization positively and significantly. Thus, adequate and timely provision of fertilizer should be carried out by agricultural unions via reasonable price. Use of organic fertilizer also should be given emphasis to boost crop production as it is environmentally friendly with less cost.

iii. The use of irrigation was found to influence positively the level of smallholder crop commercialization. Thus, government and other stalk holders should develop supplementary irrigation schemes and divert rivers accompanying by equitable use of available irrigation facilities by organizing farmers under different water use associations.

iv. Facilitating access to credit is an important pathway to commercialization for smallholders. Therefore, credit providing institutions should be strengthened financially and technically.

v. Extension organizations and other stalk holders should address adult education extensively through campaign and farmer to farmer learning.

vi. Formal and informal farmer organizations such as women associations, youth associations, water use associations, agricultural unions and cooperatives, Edir, Mehaber, and community labor cooperation (Debo, Wenfel and Jigi) should be established and strengthened by devising strategies that help to mobilize these community organizations.

\section{REFERENCES}

Abafita Jemal, Atkinson J. \& Kim C.-S. 2016. Smallholder Commercialization in Ethiopia: Market Orientation and Participation. International Food Research Journal 23(4): 1797-1807.

Addisu Getahun Tefera. 2018. Determinants of Commercialization and Market Outlet Choices of Tef: The Case of Smallholder Farmers in Dendi District of Oromia, Central Ethiopia. Master Thesis. Haramaya University, Haramaya.

Afework Hagos \& Endrias Geta. 2016. Review on smallholders' agriculture commercialization in Ethiopia: What are the driving factors to focus on? Journal of Development and Agricultural Economics. 8(4): 65-76.

Agarfa District Agricultural and Natural Resource Office. 2017. Annual Report. Agarfa, Bale.

Alelign Ademe, Belaineh Legesse, Jema Haji \& Degye Goshu. 2017. Smallholder farmers' crop commercialization in the highlands of eastern Ethiopia. Review of agricultural and applied Economics (RAAE): Vol. XX (2):30-37.

Andualem Girma Gari. 2017. Determinants of Smallholders Wheat Commercialization: The Case of Gololcha District of Bale Zone, Ethiopia. Master Thesis. University of Gondor, Ethiopia.

Asfaw Negesse Senbeta, Jema Haji, \& Bosena Tegegne. 2018. Determinants of Smallholder Farmers' Commercialization of Potato in Kofale District, West Arsi Zone. International Journal of Agriculture \& Agribusiness. Vol. 1(1): 36-48.

Assefa Tilahun, Jema Haji, Lemma Zemedu \& Dawit Alemu. 2019. Commercialization of Smallholder Pulse Producers in East Gojjam Zone, Ethiopia. Journal of Sustainable Agriculture Research. Vol. 8 (4): 84-93.

ATA (Agricultural Transformation Agency). 2017. Agricultural Transformation Agenda. Annual Report of 2016-17. Addis Ababa, Ethiopia.

Berhanu Gebremedhin \& Moti Jaleta. 2010. Commercialization of smallholders: Does market orientation translate into market participation? Improving Productivity and Market Success (IPMS) of Ethiopian farmers project Working Paper 22. Nairobi, Kenya, ILRI.

Central Statistical Agency (CSA). 2007. Population and Housing Census of Ethiopia. Results for Oromia Region, Vol. 1 (accessed 13 January 2012).

Central Statistical Agency (CSA). 2018. Agricultural Sample Survey 2017/2018 (2010 E.C.). Report on Area and Production of Major Crops (Private Peasant Holdings, Meher Season), Addis Ababa, Ethiopia. Volume I: pp.10-14.

Debebe Cheber. 2018. Smallholder Agricultural Commercialization for Income Growth and Poverty Alleviation: A Review from Ethiopian Context. Developing Country Studies, Vol.8, No.3, 2018.

Edosa Tadesa Leta. 2018. Determinants of commercialization of teff crop in AbayChomen District, HoroGuduruwallaga zone, Oromia Regional State, Ethiopia. Journal of Agricultural Extension and Rural Development. 10(12): 251-259.

Falmata Gezachew. 2018. Factors Affecting Marketing Intensity of Wheat Growers in Southeastern Ethiopia. Journal of Agricultural Science and Food Research. 9 (1): 2-3.

Getachew Eshetu. 2018. Commercialization of Smallholder Teff Producers in Jamma District, South Wollo Zone, Ethiopia. Master Thesis. Haramaya University, Haramaya.

Gutu Tesso. 2017. Climate change challenges, smallholder commercialization and progress out poverty in Ethiopia. African Development Bank, working series paper. No 253.

Kothari C.R. 2004. Research Methodology: Methods and Techniques, 2nd Edition. New Age International, New Delhi, India. 
Mendez, M. \& Popkin, B. 2004. Globalization, Urbanization and Nutritional Change in the developing world. J. Agric. Dev. Econ. 1(4):220-241.

NPC (National Planning Commission). 2016. Federal Democratic Republic of Ethiopia Growth and Transformation Plan II (GTP II) (2015/16-2019/20).Volume I: NPC May, 2016, Addis Ababa.

Osmani A.G., Islam K., Ghosh B.C. \& Hossain E. 2014. Commercialization of smallholder farmers and its welfare outcomes: Evidence from Durgapur Upazila of Rajshahi district, Bangladesh. Journal of World Economic Research. 3(6): 119-126.

Pauw S. 2017. Agricultural Commercialization in Ethiopia: A Review of Warehouse Receipts in the Maize, Wheat, Sorghum and Tef Value Chains. USAID/Ethiopia Agriculture Knowledge, Learning, Documentation and Policy Project, Addis Ababa.

Pingali L.P.1997. Agricultural Diversification in Nepal: Status, constraints and opportunities. In: Joshi PK, Gulati A, Cmminggs R (Eds.). Agricultural diversification and smallholders in South Asia. Academic Foundation, New Delhi, India, pp. 271-296.

Sharp K., Ludi E. \&Gebreselassie S. 2007. Commercialization of farming in Ethiopia: Which pathways? Ethiopian Journal of Economics. 16(1): 39-54.

Tadele Mamo, WudinehGetahun, AgajieTesfaye, Ali Chebil, Tesfaye Solomon, Aden AwHassan, TolessaDebele\& Solomon Assefa. 2017. Analysis of wheat commercialization in Ethiopia: The case of SARDSC wheat project innovation platform sites. African Journal of Agricultural Research. 2(10): 841849.

Tadesse Biru. 2007. A Double-Hurdle model of computer and internet use in American households. Department of Economics 5314. Friedmann Hall Western Michigan University Kalamazoo, MI 49008.

Tadie Mirie \& Lemma Zemedu. 2018. Determinants of market participation and intensity of marketed surplus among teff producers in Dera District of South Gondar Zone, Ethiopia. Journal of Development and Agricultural Economics. 10(10): 359-366.

Taye Melese, Abebe Birara \& Tadie Mirie. 2018. Determinants of commercialization by smallholder onion farmers in Fogera district, South Gondar Zone, Amhara national regional State, Ethiopia. Journal of Development and Agricultural Economics. 10(10): 339-351.

UNDP. 2018. Ethiopia National Human Development Report 2018; Industrialization with a Human Face. 